\title{
Determination of Crop Water Requirement and Crop Coefficient at Different Growth Stages of Green Gram Crop by Using Non-Weighing Lysimeter
}

\author{
B. Srinivas* and K.N. Tiwari
}

Agricultural and Food Engineering Department, IIT, Kharagpur, West Bengal-721302, India

*Corresponding author

\begin{tabular}{|l|}
\hline K e y w o r d s \\
Green gram, Lysimeter, \\
Crop canopy, Crop \\
Evapotranspiration (ETc), \\
Crop coefficient (Kc), \\
Reference crop \\
Evapotranspiration (ETO)
\end{tabular}

A B S T R A C T

Designing, establishing and managing irrigation projects, and scheduling irrigation requires estimating a crop seasonal water requirement. Lysimeter experiment conducted on green gram during Kharif season. His experiment was aimed at determining the seasonal crop evapotranspiration (ETc) and crop coefficient $(\mathrm{Kc})$ of green gram crop for different development stages. Three non-weighing type lysimeters with dimension of $1 \mathrm{~m} \times 1 \mathrm{~m} \times$ $1.2 \mathrm{~m}$ were used to determine the daily ETc of green gram crop. Crop coefficient $(\mathrm{Kc})$ was determined for each growth stages as the ratio of crop evapotranspiration (ETc) to that of reference crop evapotranspiration (ETo). The ETc was determined by soil water balance equation and ETo was computed by DSS-ET version 4.1. (A decision support system for estimation of crop evapotranspiration). Using FAO Penman-Monteith equation, the seasonal ETc was found to be $36.83 \mathrm{~mm}, 86.78 \mathrm{~mm}, 67.12 \mathrm{~mm}$ and $16.52 \mathrm{~mm}$ of water calculated for initial, crop development, mid-season and late season stages, respectively. The measured crop coefficient $(\mathrm{Kc})$ values were $0.34,0.45,0.57,0.69,0.8,0.99,1.05$, $1.13,1.1,1.04,0.92,0.66,0.57,0.42,0.37$ and 0.17 for the respective. Some of the crop coefficient values found in this experiment differed slightly from the average of FAO estimation but some lie in the range put for different environment. Thus, the observed difference indicates that there is a need to develop $\mathrm{Kc}$ values for a given local climate conditions and cultivars. Some crop yield and growth parameters were also collected in a sage-wise. The plant height and Number of primary, secondary and tertiary branches per plant were obtained at the mid-season stage, which was the highest from the four growth stages. The number of fruits per plant is 16 in mid-stage and 25 in late stage and the average maximum dry fruit weight per plant of Green gram was $8.12 \mathrm{gm}$.

\section{Introduction}

Different methods with different input requirements and output precisions have been developed to estimate the seasonal ETc of agricultural crops. ETc can be measured experimentally by weighing or non-weighing type lysimeters. Weighing lysimeters could provide ETc values for short periods but their installation and operation cost is quite high. Short-term ETc data is not that much useful for irrigation project planning; therefore, nonweighing type lysimeter is well suited for measuring long-term ETc data such as weekly, 
in decade or monthly which can be used in planning and management of irrigation systems (Allen et al., 1998). However, to extrapolate the measurement of ETc for irrigation planning $\mathrm{Kc}$, which is the ratio of ETc to ETo, is often required. The Kc reflects the effect of crop on the crop water requirement and can be calculated at research sites by relating the measured crop evapotranspiration using lysimeters with the calculated ETo from climatic data.

Several studies have been conducted over the years to evaluate the accuracy of different ETo methods. Most of these studies have concluded that Penman-Monteith equation in its different forms provides the best ETo estimates under most conditions. Green gram or Moong (Vigna radiata) is one of the important pulse crops in India. It has been reported that Green gram has been cultivated in India since ancient times. Green gram is a protein rich staple food and it has the high protein content $(25 \%)$. It is widely cultivated throughout the Asia. It is being cultivated in about 3.43 $\mathrm{M}$ ha in India with $9.2 \times 103$ tones production during 2015-2016 (source: Directorate of economics and statistics). In India, the important states growing this crop with a total area of about 30 lakh hectares are Orissa, Maharashtra, Andhra Pradesh, Madhya Pradesh, Gujarat, Rajasthan and Bihar. Mung bean is primarily a crop of rainy season; however, with the development of early maturing varieties, it has been proved to be an ideal crop for spring and summer seasons. The objectives of this study is to determine the of crop coefficient for green gram crop by using non-weighing types lysimeter. To determine of soil water balance parameter of moong crops using non weighing types lysimeters. To evaluate the seasonal crop water requirement (ETc) of green gram crop under Kharagpur climatic and soil condition. Lysimeter is the only device in which major terms of hydrological water balance can be determined.
Lysimeter can be defined as the device in which a volume of soil planted with vegetation is located in a container to isolate it hydrologically from the surrounding soil.

\section{Materials and Methods}

Study Area: The study was conducted at Precision Farming Development Center experimental field located at Agricultural and Food Engineering Department, Indian Institute of Technology Kharagpur. The farm is located at latitude of $22^{\circ} 19^{I} \mathrm{~N}$ and a longitude of $87^{\circ}$ $19^{1} \mathrm{E}$ with an altitude of $48 \mathrm{~m}$ above mean sea level. Kharagpur receives average annual rainfall of about $1,600 \mathrm{~mm} ; 80 \%$ of this rain occurs in the monsoon season. The mean minimum and maximum temperatures are $12^{\circ} \mathrm{C}$ in January and $46^{\circ} \mathrm{C}$ in May, respectively, and the mean relative humidity ranges from 35.5 to $90.5 \%$. The dominant soil group is sandy loam

\section{Lysimeter set-up}

Three lysimeter of $1 \mathrm{~m}$ long $\times 1 \mathrm{~m}$ wide, $\times 1.2$ $\mathrm{m}$ height dimensions were made with $1 \mathrm{~mm}$ thick iron flat plate. They were welded with 1 $1 / 2$, angle iron rod for making box, these were coated with enamel paint one lysimeter had bottom open and two were bottom closed Three Non-weighing type lysimeter were installed at the experimental field of Precision Farming Development Centre, Agricultural and Food Engineering Department, Indian Institute of Technology Kharagpur, West Bengal. While excavating the field for lysimeters installation, the soil sample from six layers at 0-15, 15-30, 30-45, 45-60, 60-75, $75-85,85-95,95-105 \mathrm{~cm}$. were collected to know the bulk density of soil in the lysimeter (Figure 1). Each lysimeter was kept at $100 \mathrm{~cm}$ below the ground surface and the soil water moving beyond $100 \mathrm{~cm}$ was considered as percolation loss. For determine soil moisture in the lysimeter FDR tubes access of $1 \mathrm{~m}$ long 
was installed in the lysimeter to $0-15,15-30$, 30-45, 45-60, and 60-75cm depth.

The evapotranspiration on Green gram crop experiments were done during Kharif growing seasons of their crop separately. A combination of two bottom open and one bottom closed lysimeter was used to measure the daily crop evapotranspiration, evaporation and deep percolation losses during the experiment conducted for Green gram crop. Crop evapotranspiration together with deep percolation $\left(\mathrm{ET}_{\mathrm{c}}+\mathrm{DP}\right)$ was measured using a bottom open lysimeter in which Green gram crop were grown (Figure 1), the percolation together with evaporation $(\mathrm{E}+\mathrm{DP})$ was measured using another bottom open lysimeter in which there was no crop (Figure 1) was grown. The evaporation (E) was measured using a bottom-closed lysimeter without crop (Figure 1). Soil in the lysimeter in the lysimeters were given same compaction to achieve same bulk density as of the experimental plots the change in soil water content inside the lysimeters was recorded daily using. Then, the values of evaporation, evapotranspiration and deep percolation at a given time were estimated using following equations.

$$
\begin{aligned}
& \mathrm{ET}_{\mathrm{c}}=\Delta \mathrm{SMC}_{\mathrm{A}}-\left(\Delta \mathrm{SMC}_{\mathrm{B}}-\Delta \mathrm{SMC}_{\mathrm{C}}\right)(1) \\
& \mathrm{DP}=\Delta \mathrm{SMC}_{\mathrm{B}}-\Delta \mathrm{SMC}_{\mathrm{C}}(2) \\
& \mathrm{E}=\Delta \mathrm{SMC}_{\mathrm{C}}(3)
\end{aligned}
$$

Where $\Delta \mathrm{SMC}_{\mathrm{A}}, \quad \Delta \mathrm{SMC}_{\mathrm{B}}, \Delta \mathrm{SMC}_{\mathrm{c}}$ Soil moisture content in the three lysimeters, and $\mathrm{A}, \mathrm{B}$, and $\mathrm{C}$ are the three lysimeters, respectively,

\section{Layout of lysimeters}

\section{Determination of crop evapotranspiration (ETc)}

Evapotranspiration of green gram and okra crops was measured using the soil water balance of the soil water content changes in the lysimeter area, considering the rainfall and irrigation and water applied from the lysimeter area was used as input. For each growth stages, the crop evapotranspiration was calculated. The estimated evapotranspiration by water balance equation was considered as the crop evapotranspiration. For the period under consideration each successive day the water, balance was calculated using the soil moisture measured in each day. The water balance equation can be expressed as follows:

$\mathrm{ETc}=\mathrm{R}+\mathrm{I}-\mathrm{Dp} \pm \Delta \mathrm{S}(4)$

Where ETc is crop evapotranspiration, I is irrigation water applied, $\mathrm{R}$ is rainfall, $\mathrm{D}$ is Dee percolation loss and $\Delta S$ is change in storage of soil moisture and all are in $\mathrm{mm}$.

Change in soil moisture $(\Delta \mathrm{S})$ is the difference in moisture content of each consecutive days and it was calculated by deducting the moisture content obtained today from previous day in each alternate days starting from sowing to the last harvest.

Calculation of reference crop evapotranspiration (ETo)

The reference crop evapotranspiration was calculated according to the FAO Penman Monteith method using DSS-ET version 4.1. (A decision support system for estimation of crop evapotranspiration). The FAO Penman Monteith equation requires air temperature, relative humidity, rainfall that was collected from weather stations. The FAO PenmanMonteith equation is expressed as:

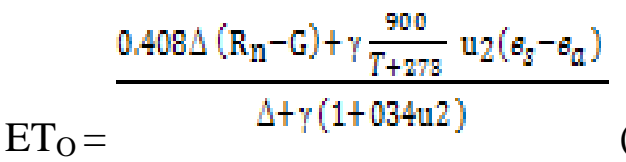

Where, $\mathrm{ET}_{\mathrm{O}}=$ Reference evapotranspiration, mm day-1 
$\mathrm{Rn}=$ Net radiation at the crop surface, $\mathrm{MJ}$ m-2 day-1

$\mathrm{G}=$ Soil heat flux density, MJ m-2 day-1

$\mathrm{T}=$ Air temperature at $2 \mathrm{~m}$ height, ${ }^{\circ} \mathrm{C}$

$\mathrm{u}_{2}=$ Wind speed at $2 \mathrm{~m}$ height, $\mathrm{m} \mathrm{s}-1$

es $=$ saturation vapour pressure $(\mathrm{kPa})$

ea $=$ actual vapour pressure $(\mathrm{kPa})$

$\Delta=$ slop vapour pressure curve $(\mathrm{kPaoC}-1)$

$\gamma=$ psychometric constant (kPaoC-1)

\section{Calculation of crop coefficient (Kc)}

Crop coefficient is defined as the ratio of crop evapotranspiration to the reference crop evapotranspiration and calculated by single and dual crop methods (Jenson et al., 1990; Allen et al., 1998). In this experiment the Kc was calculated by single crop method as the ratio of crop evapotranspiration obtained from water balance expression (eq. 4) to that of reference crop evapotranspiration obtained from FAO Penman Monteith equation (eq. 5). The crop coefficient $(\mathrm{Kc})$ was determined by following equation:

$\mathrm{K}_{\mathrm{C}}=\frac{\mathrm{ETc}}{\overline{E T \circ}(6)}$

Where, ETc and ETo are crop evapotranspiration and reference crop evapotranspiration at the various growth stages (initial, development, mid-season and late-seasons)

\section{Results and Discussion}

Soil analysis of the experimental plot and lysimeter

The results of the physical properties of the soil in each $15 \mathrm{~cm}$ layer of the soil depth up to $90 \mathrm{~cm}$ of the lysimeter. The estimated water holding capacity of the experimental soil is 28 per cent in general it is observed that the amount of moisture increased from the top layer to the bottom of the lysimeter. Field capacity varied from 24 to 28 because of clay content is more in lower layer. Similarly, bulk density varied from $1.53 \mathrm{~g} / \mathrm{cm}^{3}$ to $1.69 \mathrm{~g} / \mathrm{cm}^{3}$ which was higher at $90 \mathrm{~cm}$ depth. Bulk density refers to the compactness or looseness of a soil, higher the compaction higher the bulk density. The type of soil under which the crop is grown has influence on the availability of water to the crop. The textural class of soil, which dominates the experimental lysimeter, is sandy loam (Table 1). Crop evapotranspiration is satisfied by the amount of water held by soil particle. The particle size distribution of the soil in five depths shows higher values of clay content hence more is the value of water holding capacity of soil.

\section{Water Balance Study}

Crop evapotranspiration (ETc) of Green gram showed an increasing from the 20 DAS to the 32 DAS and started to decline from 52 DAS to 64 DAS period as shown in table 5.2. This implies that there was lesser ET of the crop at the initial stage. In the second stage (Development stage), there was an increase in ETc starting from 30 DAS to 50 DAS. During mid-season stage 20 DAS to 35 DAS the ETc was almost constant as compared to the other stages.

The highest crop ET was obtained in midseason stage at the 32 DAS. Finally, at the late-season stage the crop ET showed a decreasing trend, which resulted from senescence of leaves and it was the sign of maturity and declining of growth and development of the crop. The maximum water use was $88.78 \mathrm{~mm}$ at the mid-season stage while development stage was $58.72 \mathrm{~mm}$.

Late-season and initial stages hold the third and least crop ET, respectively. The highest ETc of green gram crop was found to be 5.28 $\mathrm{mm} /$ day, which was recorded at 32 DAS. 


\section{Leaf area index}

The amount of moisture transpired by the crop and evaporated from bare soil to satisfy the demand of the atmosphere is associated with the leaf area development and canopy cover, which increases or decreases the area that will be exposed to direct sun light. The relationship between percent canopy cover and leaf area index and their influence on crop evapotranspiration and crop coefficient. The amount of growth is measured in every growth period after 10, 30, 40, 60 days for initial, development, mid-season and late-seasons respectively.

The ground cover of leaf shadow has a role in reducing the amount of water that evaporates from a bare soil. Allen et al., (1998) has also indicated that at initial stage nearly $100 \%$ of ET comes from evaporation, while crop full cover at the mid-season stage more than $90 \%$ of ET comes from transpiration. Kc value is constantly rising at this stage due to an increased crop evapotranspiration, which resulted from increment of leaf area of the transpiring leaf.

During mid-season stage the crop attained peak value of leaf area index and canopy, cover. These increased the proportion of leaf area exposed to direct sun light, as a result it raised the ETc and $\mathrm{Kc}$ of the crop. Late-season stage is the stage where decline of every activities are observed.

At this stage, ETc of the crop is slowing down due to senescence and aging of the transpiring leaves. every growth stage are $0.91,2.05$, $3.36,3.70,4.94$, and $4.54 \mathrm{~m} 2 / \mathrm{m} 2$ for initial, crop development, mid-season and lateseasons respectively, after 30 to 50 days proportion of soil exposed to direct sun light decreased from around $90 \%$. The maximum ETc and $\mathrm{Kc}$ of green gram crop is obtained at mid-season stage and the value of leaf area and canopy cover is the highest at this stage as observed in (Fig. 2). The size of canopy has a direct influence on evapotranspiration of crops (Paraskevas et al., 2012).

\section{Reference crop evapotranspiration and actual crop evapotranspiration}

The $\mathrm{ET}_{\mathrm{O}}$ attained its maximum during the initial crop growth stage, which could be attributed to the high evaporative demand of the atmosphere (Figure 2). There was a decrease in $\mathrm{ET}_{\mathrm{O}}$ from the initial to the end of the late season stage with fluctuating trend, which was attributed to the variability of climatologically factors during the growing season.

Moreover, the ETc exceeded ETo during 28 48 days after sowing which coincided with the mid-season stage of the crop demand for high water use due to flowering, grains formation and filling. The rapid decrease in ETc at the end of mid-season to late season stage (Figure 3) was due to leaf senescence and to the completion of grain formation and filling thereby limiting transpiration.

The crop water use declined in the late season stage, which was due to the cessation of leaf growth (Allen et al., 1998).

\section{Crop coefficient}

The crop coefficient is the ratio of reference crop evapotranspiration to the crop evapotranspiration. The ETc calculating using daily soil moisture data and ETO was calculated as by using metrological data, were four days Kc values are developed for green gram crop. The values of crop coefficient for green gram are given in Figure 4. Kc is high during the periods where crop evapotranspiration exceeds the reference crop evapotranspiration during the experimental periods. 
Table.1 Estimated water balance components at 4 days interval after sowing of Green gram crop in the lysimeter

\begin{tabular}{|c|c|c|c|c|}
\hline \multicolumn{5}{|c|}{ Water balance components estimated at 4 days interval } \\
\hline DAS & Stage & Irr $(\mathbf{m m})$ & DP $(\mathbf{m m})$ & ETc $(\mathbf{m m})$ \\
\hline $\mathbf{4}$ & IS & 10.24 & 4.6 & 5.64 \\
\hline $\mathbf{8}$ & IS & 12.29 & 4.12 & 8.11 \\
\hline $\mathbf{1 2}$ & IS & 14.29 & 4.09 & 10.88 \\
\hline $\mathbf{1 6}$ & IS & 16.89 & 4.01 & 12.88 \\
\hline $\mathbf{2 0}$ & DS & 17.07 & 3.57 & 13.48 \\
\hline $\mathbf{2 4}$ & DS & 18.85 & 3.51 & 15.34 \\
\hline $\mathbf{2 8}$ & DS & 20.46 & 3.40 & 17.04 \\
\hline $\mathbf{3 2}$ & DS & 24.55 & 3.39 & 21.16 \\
\hline $\mathbf{3 6}$ & DS & 22.89 & 3.13 & 19.76 \\
\hline $\mathbf{4 0}$ & MS & 18.99 & 3.11 & 15.88 \\
\hline $\mathbf{4 4}$ & MS & 20.41 & 3.05 & 17.36 \\
\hline $\mathbf{4 8}$ & MS & 17.37 & 3.01 & 14.36 \\
\hline $\mathbf{5 2}$ & MS & 13.12 & 2.08 & 11.12 \\
\hline $\mathbf{5 6}$ & MS & 10.49 & 2.03 & 8.4 \\
\hline $\mathbf{6 0}$ & LS & 9.13 & 2.01 & 7.12 \\
\hline $\mathbf{6 4}$ & LS & 8.52 & 2.0 & 6.52 \\
\hline $\mathbf{6 7}$ & LS & 4.72 & 1.87 & 2.88 \\
\hline Total & & $\mathbf{2 6 3 . 4 8}$ & $\mathbf{5 2 . 9 8}$ & $\mathbf{2 1 0 . 5 4}$ \\
\hline
\end{tabular}

DAS: Days after crop sown, Irr: Irrigation, DP: Depercolation, ETc: Crop evapotranspiration, IS: initial stage, DS: Development stage, MS: Mid-season stage and LS: Late-season stage.

Table.2 Stage wise crop coefficient $(\mathrm{Kc})$ values during the growing season

\begin{tabular}{|l|c|c|c|c|}
\hline & Initial & Development & Mid-season & Late season \\
\hline $\mathrm{K}_{\mathrm{c}}$ & $0.34-0.57$ & $0.79-0.98$ & $1.13-0.92$ & $0.66-0.17$ \\
\hline FAO K & $0.35-0.58$ & $0.80-0.99$ & $1.14-1.04$ & $0.67-0.18$ \\
\hline
\end{tabular}

$\mathrm{Kc}=$ Crop Coefficient and $\mathrm{FAO}=$ Food and Agricultural Organization

Table.3 Stage-wise growth and yield parameters of green gram grown in lysimeter

\begin{tabular}{|l|c|c|c|c|}
\hline \multicolumn{5}{|c|}{ Growth Stages } \\
\hline Parameters & Initial & Developme & Mid- & Late- \\
\hline Plant height $(\mathrm{cm})$ & 5.6 & 10.2 & 14.4 & 17.9 \\
\hline Number of branch/plant & 3 & 5 & 5 & 7 \\
\hline Number of fruits/plant & - & - & 16 & 25 \\
\hline Weight of dry fruit/plant $(\mathrm{g})$ & - & - & - & 8.125 \\
\hline Yield of lysimeter Area $1 \mathrm{~m}^{2}(\mathrm{~kg})$ & & & & 0.13 \\
\hline Total yield, $(\mathrm{q} / \mathrm{ha})$ & - & - & - & 0.067 \\
\hline
\end{tabular}


Fig.1 Conceptual diagram shows measurement of change in soil moisture content A, B, C, in a Green gram and okra crops during growing period

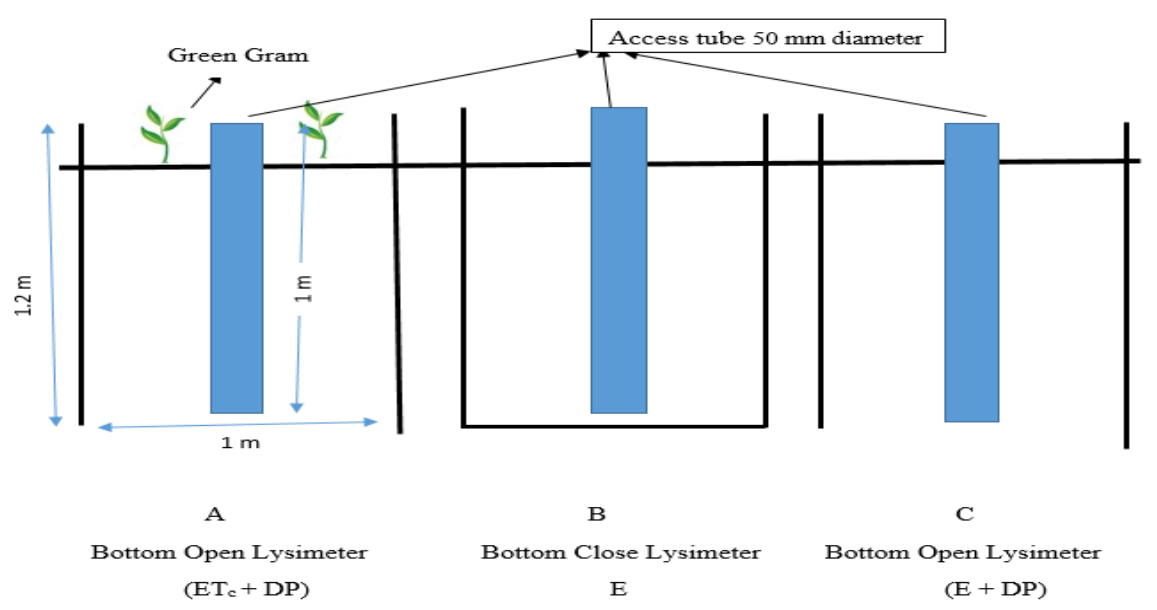

Fig.2 Leaf area index at different growth stages

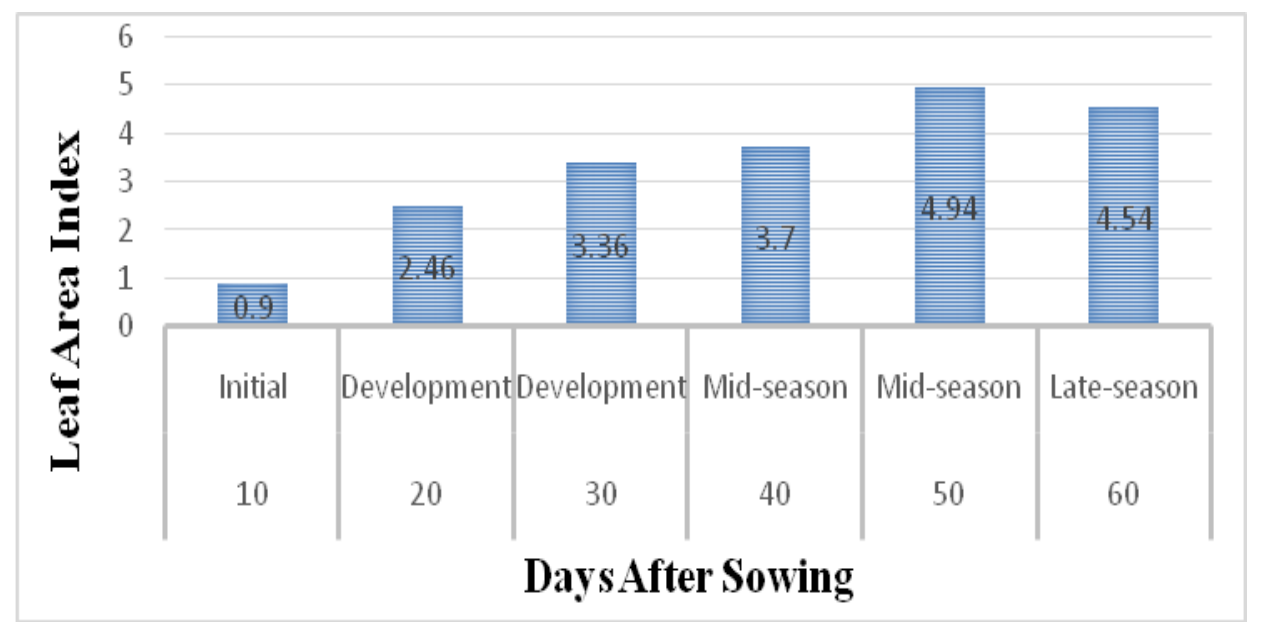

Fig.3 Seasonal ETC and ETO of green gram crop as a function of days after sowing

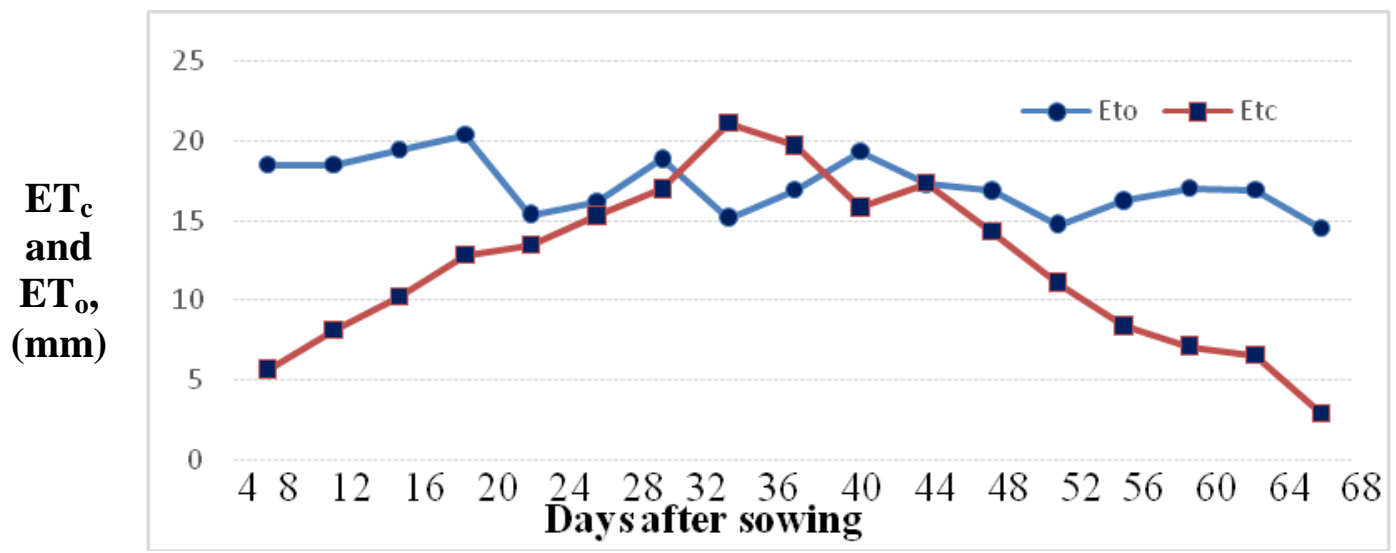


Fig.4 Four-day Kc values of green gram crop growing season and standard FAO Kc curve

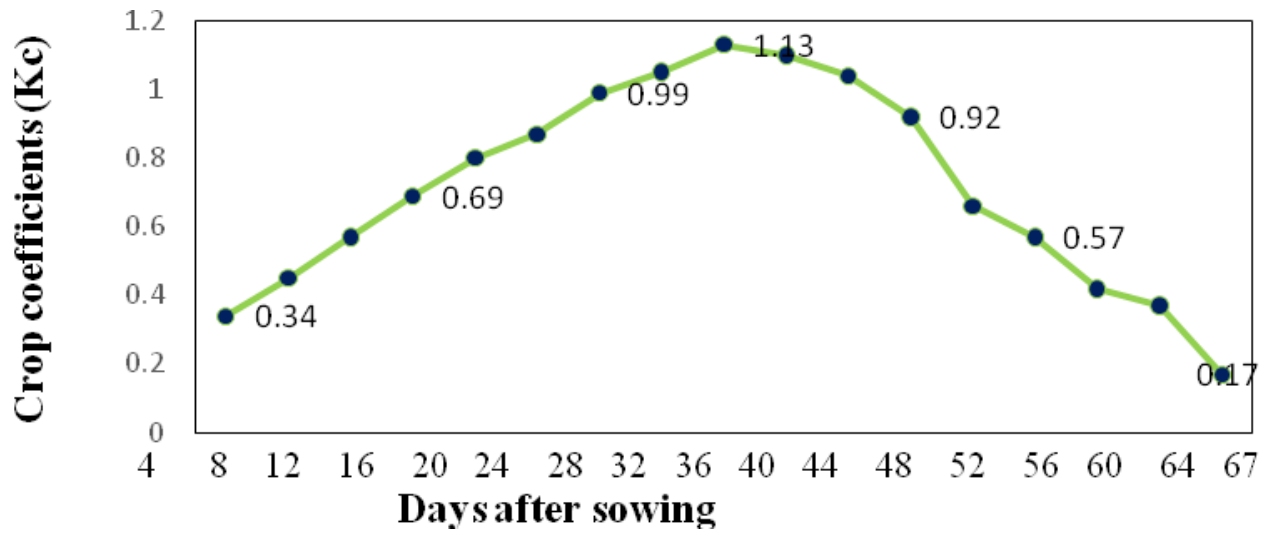

The ET of the crop is higher only at midseason stage where as in the rest stages ETO are higher than ETc Crop coefficient value of a given crop is a factor, which dictates the evapotranspiration of the crop. At the initial stage $\mathrm{Kc}$, values are higher when the soil is wet by irrigation or rainfall, and low when the top soil is dry. The seasonal Kc value of green gram is least at 20 DAS due to smaller leaf area, reduced transpiration, and shows a constant rise in the crop development stage.

During the mid-season stage, highest value of $\mathrm{Kc}$ is obtained which is an indication of maximum evapotranspiration (Figure 4). At the last, stage 55 to 67 DAS, the crop coefficient value decreased steadily due to maturity and senescence of leaf. The Kc integrates the effect of characteristics that distinguish a typical field crop from the grass reference, which has a constant appearance and a complete ground cover. The changing characteristic of the crop over the growing season has an effect on the Kc.

As evaporation was an integrated part of crop ET, conditions affecting soil evaporation has also an effect on the Kc. The $\mathrm{Kc}$ values increased from initial value of 0.34 to midseason value of 1.13 and the late- season $\mathrm{Kc}$ value was found to be 0.66 as given in (Table 2).

\section{Crop growth parameter}

Crop evapotranspiration and crop coefficient are the result of different crop physiological and morphological characters. In the course of the experiment different crop, parameters were recorded in lysimeters and the buffer area at each crop growth stages in each week (Table 4). Plant height increased from initial stage of $5.6 \mathrm{~cm}$ to $14.4 \mathrm{~cm}$ at mid-season stage. The maximum rise in plant height was observed from mid to late season stage. In this cultivar, the maximum plant height was found to be $17.9 \mathrm{~cm}$. Similarly, the highest number of branches per plant was recorded at midseason stage and there was no much more branches obtained at late-season stage. The number of fruits per plant is 16 in mid-stage and 25 in late stage and weight of dry fruits per plant is $8.12 \mathrm{gm}$ per plant, and the total yield of lysimeter area is $0.13 \mathrm{~kg}$ and total yield of inside and outside of the area is 0.067 $\mathrm{q} / \mathrm{ha}$, was recorded, respectively.

For most crops grown in the country locally estimated ETc and $\mathrm{Kc}$ values are not available. Determining ETc and $\mathrm{Kc}$ of agricultural crops helps to have appropriate irrigation schedule, wise management of irrigation water and designing and managing irrigated projects. This research aimed at establishing stage wise ETc and Kc value of 
green gram crop under Kharagpur, West Bengal climatic and soil condition. The experiment was conducted at PFDC experimental farm of Agricultural and Food Engineering Department IIT Kharagpur, to determine the seasonal crop water requirement $(\mathrm{ETc})$ and crop coefficient $(\mathrm{Kc})$ of green gram crop for the different growth stages. Three non-wedging type lysimeters were employed to determine the seasonal water use of green gram crop. ETc was calculated using water balance equation and ETo was determined by FAO-Penman Monteith equation. The ratio of ETc to that of the ETo was taken as Kc of the crop at each respective growth stages and the sum of each stages ETc were taken as seasonal ETc of green gram crop. The length of the four growth stages was estimated by calculating the canopy development and soil coverage of the shadow. The length of each growth stages were identified as 15, 30, 45 and 60 days for initial, development, mid-season and lateseason stages, respectively. From the results of this research, the seasonal ETc of green gram is $210.54 \mathrm{~mm}$ with the ETc for initial, development, mid-season and late-season being 36.83, 86.78, 67.12 and $16.52 \mathrm{~mm}$, respectively. With respect to $\mathrm{Kc}$, it is estimated to be $0.34,0.98,1.13$, and 0.17 for initial, development, mid-season and lateseason stages, respectively

\section{References}

Abedinpour M., 2015. Evaluation of growthstage-specific crop coefficients of maize using weighing lysimeter. Soil \& Water Res., 10: 99-104. 10.17221/63/2014SWR.

Allen, R. G., R. W. Hill, and S. Vemulapali, 1994. Evapotranspiration Parameters for Variably- Sized Wetlands. Paper presented at the 1994 Summer Meeting of ASAE. No 942132: `P. 24.
Allen, R., L. Pereira, D. Raes and M. Smith, 1998. Crop evapotranspiration; guidelines for computing crop water requirements. Food and Agricultural Organization, Irrigation and Drainage Paper No. 56, Rome, Italy.

Daniel K. and Fisher. 2012. Simple weighing lysimeters for measuring evapotranspiration 11 and developing crop coefficients, nt J Agric \& Biol Eng., Vol. 5 No.3 (35)

David, R. Bryla, Thomas J. Trout., and James E. Ayars. 2010. Weighing Lysimeters for Developing Crop Coefficients and Efficient Irrigation Practices for Vegetable Crops, Hortscience vol. 45(11) November 2010

Doorenbos, J. and W. O. Pruitt, 1977. Guidelines for computing crop water requirements. Food and Agricultural Organization. Irrigation and Drainage Paper No-24. Rome, Italy.

FAO (Food and Agricultural Organization), 2002. Deficient Irrigation practice. Food and Agriculture organization of the united nation. Water reports. No. 22. Rome, Italy.

Kashyap, P. S. and R. K. Panda, 2001. Evaluation of evapotranspiration estimation methods and development of crop coefficient for potato crop in sub humid regions. Agricultural Water Management, 26 (1993): PP. 67-80.

Kassam, A.A, J.M Kowal and C. Harkness, 1975. Water use and growth of groundnut at Samaru, Northern Nigeria. Journal of Tropical Agriculture, 52: 105-112.

Paraskevas1, C., P. Georgiou1, A. Ilias2, A. Panoras2, and C. Babajimopoulos2012. Evapotranspiration and simulation of soil water movement in small area vegetation, Int. Agrophys., 2013, 27, 445-453, doi: 10.2478/intag-2013-0015.

Piccinni, G., J. KO, T. Marek and T. Howell, 2006. Determination of growth-stage- 
specific crop coefficients $(\mathrm{Kc})$ of maize and sorghum: Chesterfield, USA. Journal of Agricultural Water Management, 96: 1698-1704.

Taygi, N.K., D.K. Sharma and S. K. Luthra, 2000. evapotranspiration and crop coefficients of rice and sunflower with lysimeter. Agricultural Water management 45(2000).

\section{How to cite this article:}

Srinivas, B. and Tiwari, K.N. 2018. Determination of Crop Water Requirement and Crop Coefficient at Different Growth Stages of Green Gram Crop by Using Non-Weighing Lysimeter. Int.J.Curr.Microbiol.App.Sci. 7(09): 2580-2589. doi: https://doi.org/10.20546/ijcmas.2018.709.321 